\title{
Flusilazole Induced Cytotoxicity and Inhibition of Neuronal Growth in Differentiated SH-SY5Y Neuroblastoma Cells by All-Trans-Retinoic Acid (Atra)
}

\author{
All-Trans-Retinoik Asit (Atra) ile Farklılaştırılmış SH-SY5Y Nöroblastoma \\ Hücrelerinde Flusilazole Bağlı Sitotoksisite ve Nöronal Büyüme İnhibisyonu
}

\author{
(D) Elif KARACAOĞLU* \\ Hacettepe University Faculty of Science, Department of Biology, Ankara, Turkey
}

\begin{abstract}
Objectives: Flusilazole (FLUS) is a broad-spectrum organosilicon triazole fungicide used for protecting economically important cereals and orchard fruits. Considering the exposure route of pesticides, pesticide contamination of food is inevitable. Furthermore, excessive exposure to pesticides causes health problems in both target and non-target organisms. It was aimed to evaluate the effects of the triazole fungicide FLUS on cytotoxicity and neurite extension in differentiated SH-SY5Y neuroblastoma cells.

Materials and Methods: The SH-SY5Y cells were differentiated into mature neurons using 10- $\mu \mathrm{M}$ all-trans-retinoic acid (RA) treatment for 7 days. Then the differentiated SH-SY5Y cells were treated with 50, 100 and $200 \mu \mathrm{M}$ FLUS for $24 \mathrm{~h}$. Afterwards, cell viability assays were performed including crystal violet, neutral red cell viability, and lactate dehydrogenase leakage assays. The morphological examinations were performed and neurite lenghts of the cells were measured in all experimental groups.

Results: FLUS treatment induced cytotoxicity in SH-SY5Y cells differentiated with RA. Significant decreases in cell viability percentages were observed. Furthermore, neurite lengths were negatively affected by the treatment of FLUS at the highest concentration.

Conclusion: FLUS is a fungicide widely used in agriculture to protect crops from fungal diseases. However, the intensive use of these compounds causes a potential risk to human and environmental health. According to the results of the study, it can be concluded that high concentrations of FLUS cause neurotoxicity by causing neural cell death and adverse effects on neurite outgrowth in differentiated SH-SY5Y cells. FLUS exposure can cause neuronal degeneration in mammals.
\end{abstract}

Key words: Flusilazole, cytotoxicity, SH-SY5Y cell differentiation, neurite growth

öz

Amaç: Flusilazol (FLUS) ekonomik açıdan önemli tahıl ve tahıl ürünlerini ve meyve bahçelerini korumak için kullanılan geniş spektrumlu bir organosilikonlu triazol fungisittir. Pestisitlerin maruziyet yolları dikkate alındığında besin yoluyla pestisit maruziyeti kaçınılmaz olmaktadır. Ayrıca pestisitlere așırı derecede maruz kalmak hedef ve hedef olmayan organizmalarda sağlık sorunlarına neden olmaktadır. Çalıșmanın amacı, bir triazol fungisit olan FLUS'nin farklılaștırılmıș SH-SY5Y nöroblastoma hücrelerinde sitotoksisite ve nörit uzaması üzerine etkilerinin değerlendirilmesidir. Gereç ve Yöntemler: SH-SY5Y hücreleri $10 \mu \mathrm{M}$ all-trans retinoik asit (RA) ile 7 gün boyunca olgun nöronlara farklılaștırılmıştır. Farklılaştırılmış SHSY5Y hücreleri 50, 100 ve 200 M FLUS ile 24 saat boyunca muamele edilmiștir. Kristal viyole, nötral kırmızısı canlılık testleri ile laktat dehidrogenaz salım testlerini kapsayan hücre canlılık testleri yapılmıştır. Ek olarak, morfolojik incelemeler yapılmış ve hücrelerin nörit uzunlukları ölçülmüştür.

Bulgular: FLUS uygulaması RA ile farklılaştırılan SH-SY5Y hücrelerinde sitotoksisiteyi indüklemiștir. Hücre canlılık yüzdelerinde dikkate değer düşüșler gözlenmiștir. Ayrıca en yüksek konsantrasyondaki FLUS uygulaması ile nörit uzunlukları olumsuz yönde etkilenmiștir.

Sonuç: FLUS tarımda ekinleri fungal hastalıklardan koruma amacıyla yaygın olarak kullanılan bir fungisittir. Fakat bu bileșiklerin yoğun kullanımı insan ve çevre sağlığı açısından potansiyel risk oluşturmaktadır. Çalışma sonuçlarına göre, yüksek konsantrasyonlarda FLUS'nin farklılaştırılmış SHSY5Y hücrelerinde nöral hücre ölümüne ve nörit büyümesinde olumsuz etkilere neden olarak nörotoksisiteye yol açtığı sonucu çıkarılabilir. FLUS maruziyeti memelilerde nöronal dejenerasyona neden olabilir.

Anahtar kelimeler: Flusilazol, sitotoksisite, SH-SY5Y hücre farklılaşması, nörit büyümesi

*Correspondence: elif.kus@hacettepe.edu.tr, Phone: +90 31229780 38, ORCID-ID: orcid.org/0000-0003-3426-4584

Received: 09.01.2021, Accepted: 17.02.2021

-Turk J Pharm Sci, Published by Galenos Publishing House. 


\section{INTRODUCTION}

The use of pesticides in agriculture enhances the production quality of food and feeds. However, it causes several health problems due to environmental and food contaminations. Among these pesticides, triazole fungicides are commonly used in agriculture for preventing fungal infections in fruits, cereals, and vegetables and have pharmacological uses for human and animal health., ${ }^{12}$ Consequently, flusilazole (FLUS) is a broad-spectrum organosilicon triazole fungicide that is used for protecting economically important cereals and orchard fruits. ${ }^{3.4}$ Its action mechanism can be attributed to the inhibition of the lanosterol 14 alpha-demethylase (CYP51) enzyme that plays a key role in sterol biosynthesis in fungus. ${ }^{5}$ The CYP51 inhibition causes a reduction in the synthesis of ergosterol, which is the basic element of the fungal cell wall and prevents fungal cell growth. Consequently, the cell growth inhibition results in fungal cell death. As CYP51 enzyme exists in human, studies have reported that CYP51 inhibition caused by triazole fungicides can adversely affect mammalian cells. ${ }^{6}$ Previous in vitro and in vivo studies asserted that triazole fungicides have adverse effects on mammalian steroidogenesis and may induce developmental toxicity such as craniofacial malformations. ${ }^{7.8}$ One study revealed that the estimated acceptable daily intake of FLUS is about $0-0.007 \mathrm{mg} / \mathrm{kg}$ bw for humans. ${ }^{9}$ However, considering the exposure route of pesticides, pesticide contamination of food is inevitable and excessive exposure to pesticides can cause health problems on both target and non-target organisms. Although previous studies have already focused on cytotoxicity and oxidative stress of FLUS on dopaminergic PC12 cells, ${ }^{6}$ it is believed that the present study is the first to reveal the effects of FLUS on neurite growth and to compare cytotoxicity assays on differentiated $\mathrm{SH}-\mathrm{SY} 5 \mathrm{Y}$ cells.

The human neuroblastoma cell line SH-SY5Y cells are commonly used in neurotoxicity and neurodegenerative disease models. ${ }^{10}$ In vitro models of SH-SY5Y can be differentiated into mature dopaminergic neuron-like phenotype via the induction of retinoic acid (RA)," which is known to regulate the cell cycle..$^{2}$ This differentiation of the neuronal cells in experimental studies could provide homogenous neuronal cells." Additionally, studies have shown that RA-induced differentiation can elevate the susceptibility of SH-SY5Y cells against neurotoxins and protective agents. ${ }^{13}$ Furthermore, differentiated SH-SY5Y cells are known to serve as a good model for studying experimental Parkinson's disease model. ${ }^{13}$ The increased incidence of neurological diseases in recent years has necessitated the increase in experimental studies evaluating the relationship between chemicals and diseases. As exposure to environmental contaminants is inevitable, revealing the potential neurotoxicity effects of commonly used fungicides is important. In the present study, it is aimed to evaluate the effects of FLUS on neurite extension in differentiated SH-SY5Y neuroblastoma cells and to compare three commonly used cytotoxicity tests.

\section{MATERIALS AND METHODS}

Cell culture conditions and differentiation of SH-SY5Y cells

SH-SY5Y human neuroblastoma cells purchased from American Type Culture Collection (ATCC ${ }^{\circledR}$ CRL-2266 ${ }^{\mathrm{T}}$, ATCC,
VA, USA), which was cultured with Dulbecco's minimum essential medium/nutrient mixture F-12 (DMEM/F-12) (Cegrogen Biotech $\mathrm{GmbH}$, Germany) supplemented by $10 \%$ fetal bovine serum (FBS) (Cegrogen Biotech GmbH, Germany) and $1 \%$ penicillin-streptomycin antibiotic mixture at $37^{\circ} \mathrm{C}$ with $5 \% \mathrm{CO}_{2}$ in a humidified incubator. The culture medium was renewed every 3 days and subcultured the cells by detaching them with trypsin ethylenediaminetetraacetic acid (0.05\%) in Dulbecco's phosphate-buffered saline (Cegrogen Biotech $\mathrm{GmbH}$, Germany). SH-SY5Y cells then was incubated for $48 \mathrm{~h}$ for attachment. Finally, the culture medium was replaced with differentiation medium (DMEM supplemented with $3 \%$ FBS and $10 \mu \mathrm{M}$ all-trans-RA) for 7 days until treatment in the dark at $37^{\circ} \mathrm{C}$ with $5 \% \mathrm{CO}_{2}$ in a humidified incubator.

\section{Treatment of FLUS}

First, FLUS was dissolved (PESTANAL ${ }^{\circledR}$, analytical standard, Merck KGaA, Darmstadt, Germany) in dimethyl sulfoxide (Applichem, Darmstadt, Germany) to prepare $0.1 \mathrm{~g} / \mathrm{mL}$ stock solution. Then the working concentrations were prepared by diluting the stock solution with cell culture medium. Next, the differentiated SH-SY5Y cells were incubated with 0-500 $\mu \mathrm{M}$ FLUS concentrations and performed crystal violet cell viability assay to calculate the $\mathrm{IC}_{50}$, which was found at $182.42 \mu \mathrm{M}$. The cell viability $(15 \%)$ at high concentrations $(500 \mu \mathrm{M})$ was found very toxic. The working concentrations were based on the calculated $\mathrm{IC}_{50}$ value for further analyses. It is defined low and middle doses as those with slightly toxic concentrations lower than the $\mathrm{IC}_{50}$ and for high dose selection while high doses are those with concentrations higher than the $\mathrm{IC}_{50}$ value. Finally, 50-, 100-, and 200- $\mu \mathrm{M}$ FLUS concentrations were selected for further analyses.

\section{Crystal violet cell viability assay}

First, the differentiated SY-SY5Y cells were seeded at $1 \times 10^{4}$ cells/well into a 96-well culture plate and incubated them for $24 \mathrm{~h}$ for cell attachment. Then the cells were treated with 0 , 50,100 , and $200 \mu \mathrm{M} \mathrm{FLUS} \mathrm{at} 37^{\circ} \mathrm{C}$ and $5 \% \mathrm{CO}_{2}$ in a humidified incubator for $24 \mathrm{~h}$ after which we performed a crystal violet cell viability assay. ${ }^{14}$ Briefly, the culture medium was discarded with FLUS and mixed the cells with $4 \%$ neutral buffered formalin for $1 \mathrm{~h}$. After removing the fixative, the cells was stained with $0.1 \%$ crystal violet solution for $30 \mathrm{~min}$ on a shaker at room temperature. The cells then were washed with distilled water several times to remove excess crystal violet dye. The crystal violet dye was extracted in the cells using $10 \%$ acetic acid solution until the dye was dissolved and then measured the absorbance at $595 \mathrm{~nm}$ wavelength using a microplate spectrophotometer (BIO-TEK $\mu$ Quant, BIO-TEK Instruments, Inc., USA). Finally, the cell viability was calculated based on the $100 \%$ viability of untreated cells.

\section{Neutral red uptake assay}

Similarly, the differentiated SH-SY5Y cells were seeded into a 96-well culture plate at a density of $1 \times 10^{4}$ cells/well and allowed them to attach onto the surface and grow for $24 \mathrm{~h}$. Afterwards, the cells were treated with FLUS concentrations $(0,50,100$, $200 \mu \mathrm{M})$ and were incubated at $37^{\circ} \mathrm{C}$ and $5 \% \mathrm{CO}_{2}$ in a humidified 
incubator for $24 \mathrm{~h}$. A neutral red uptake assay was performed to determine the cell viability. Briefly, the differentiated SH-SY5Y cells were incubated with $40 \mu \mathrm{g} / \mathrm{mL}$ neutral red dye containing the culture media for $4 \mathrm{~h}$ at $37^{\circ} \mathrm{C}$ and $5 \% \mathrm{CO}_{2}$ in a humidified incubator. Then the culture medium was discarded, the cells were washed twice with phosphate buffer saline twice, and extracted the dye using a neutral red desorb solution ( $1 \%$ glacial acetic acid, $50 \%$ ethanol in distilled water) for $20-45 \mathrm{~min}$ on a shaker at room temperature. Afterwards, the absorbance was measured at $540 \mathrm{~nm}$ wavelength for $1 \mathrm{~h}$ using a microplate spectrophotometer (BIO-TEK $\mu$ Quant, BIO-TEK Instruments, Inc., USA). Finally, the cell viability was calculated based on the $100 \%$ viability of untreated cells.

\section{Lactate dehydrogenase ( $L D H$ ) leakage assay}

$\mathrm{LDH}$ is a stable cytosolic enzyme that is released from cells when cell membrane damage occurs. Consequently, LDH leakage assay is commonly used to determine cell membrane damage. We performed an LDH assay using a commercial kit (Biovision, K313-500, USA). Briefly, the differentiated SY-SY5Y cells were seeded at a density of $2 \times 10^{4}$ cells/well into a 96-well culture plate and incubated them at $37^{\circ} \mathrm{C}$ and $5 \% \mathrm{CO}_{2}$ in a humidified incubator for $24 \mathrm{~h}$. Then the culture medium was discarded and the cells were treated with FLUS concentrations $(0,50,100$, and $200 \mu \mathrm{M}$ ) for $24 \mathrm{~h}$. At the end of the incubation time, the cells were centrifuged at $600 \mathrm{~g}$ for 10 min using a plate rotor (5810R Centrifuge, Ependorf AG, Hamburg, Germany). Afterwards, I incubated $10 \mu \mathrm{L}$ sample with $100 \mu \mathrm{L} \mathrm{LDH}$ reaction solution for $30 \mathrm{~min}$ in the dark at room temperature. This assay utilizes the enzymatic coupling reaction in which LDH oxidized lactate to generate nicotinamide adenine dinucleotide and where the water-soluble tetrazolium salt present in the reaction solution generates yellow to amber color. The generated color intensity directly correlates with the damaged cell amount. Finally, at the end of the incubation time, we measured the absorbance at 450 $\mathrm{nm}$ wavelength using a microplate spectrophotometer (BIOTEK $\mu$ Quant, BIO-TEK Instruments, Inc., USA). The percentage of the cytotoxicity was calculated based on the $100 \%$ viability of untreated cells.

\section{Cell morphology analysis}

The cell mofphology analysis was performed by capturing micrographs of undifferentiated or differentiated treated cells using an inverted microscope (Olympus CKX 41 inverted microscope, CellSence Imaging Software, Olympus, Japan). Each experiment was performed by measuring the neurite lengths of undifferentiated or differentiated neurons using an Image J Package with Neuron J.15,16

\section{Statistical analysis}

The statistical analyses were performed using the package program of SPSS for Windows and calculated the $\mathrm{IC}_{50}$ value through probit analysis. In order to determine the significant differences between FLUS treatment and non-treatment groups, ANOVA test was performed with 95\% confidence interval followed by Tukey post-hoc test. The data were expressed as mean \pm standard error. All experiments were performed in independent triplicates.

\section{RESULTS}

\section{Morphological features of undifferentiated and differentiated} SH-SY5Y cells

The SH-SY5Y cells were differentiated by treating them with 10 $\mu \mathrm{M}$ RA for 7 days. Figure 1 demonstrates morphological features of undifferentiated and differentiated cells. Undifferentiated cells can be distinguished by the presence of clustered round cells and short neurites (Figure 1A). On the other hand, morphologically differentiated $\mathrm{SH}-\mathrm{SY} 5 \mathrm{Y}$ cells are characterized by extensive neurites as well as pyramid-shaped cells (Figure 1B). To better distinguish the differences, the neurite lengths of undifferentiated and differentiated SH-SY5Y cells were measured, as shown in Figure $1 \mathrm{C}$. While undifferentiated cells showed shorter neurites, neurites were longer in cells that underwent 7-day RA-induced differentiation. Differentiated SHSY5Y cells were treated with different FLUS concentrations. Figure 2 demonstrates the morphological effects of FLUS on RA-induced differentiated SH-SY5Y cells. Accordingly, results showed that FLUS treatment caused remarkable morphological changes in differentiated SH-SY5Y cells, including apoptotic cell death, which is characterized by round and small nuclei and a decrease in neurite length (Figure 2). Apoptotic cells increased in FLUS treatment groups, and neurite length decreased in response to the highest FLUS concentration, which was statistically significant compared with those in the non-treatment group.
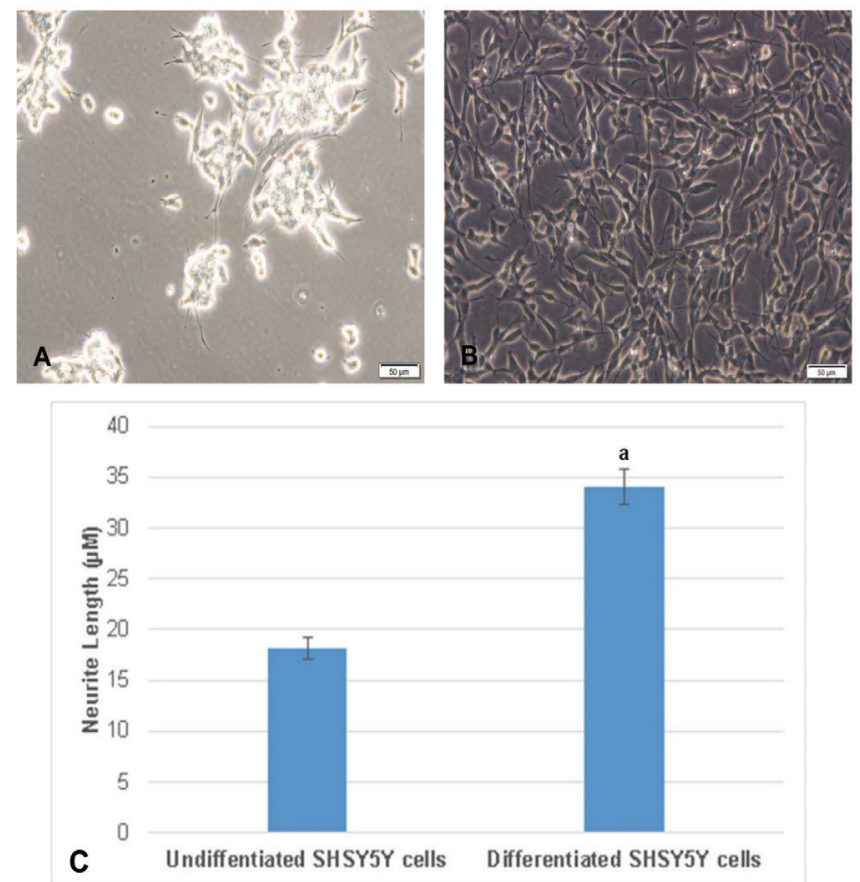

Figure 1. A) Undifferentiated SH-SY5Y cells with clustered, round-shaped cell body and short neurites; B) RA-induced differentiated SH-SY5Y cells with pyramidal-shaped cell body and extended neurites; C) neurite lengths of undifferentiated and differentiated SH-SY5Y cells

RA: Retinoic acid 


\section{Cell viability assay results}

The cytotoxic effects of FLUS was evaluated by performing different cytotoxicity assays (i.e., crystal violet, LDH, and neutral red cell viability assays). Crystal violet assay revealed an $\mathrm{IC}_{50}$ value of $182.42 \mu \mathrm{M}$, which was the basis of our working concentrations. As demonstrated in Figure 3, the decrease in cell viability was statistically significant in $100-$ and $200-\mu \mathrm{M}$ FLUS treatment groups as compared with that in the control and

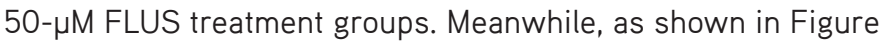
4 , LDH leakage assay results revealed that occurrences of cell death increased in response to increasing FLUS concentrations. At higher concentrations, FLUS increased the percentage of cell death viability, which was statistically significant in the 100- and 200- $\mu \mathrm{M}$ FLUS treatment groups when compared with that in the non-treatment and 50- $\mu \mathrm{M}$ FLUS treatment groups. On the other hand, according to neutral red cell viability assay results (Figure 5), remarkable decreases in cell viability were statistically significant in all treatment groups. Significant decreases were found between non-treatment and FLUS treatment groups. Additionally, the cell viability in the 200- $\mu \mathrm{M}$ FLUS treatment group was significantly different from that in the 50- and 100- $\mu \mathrm{M}$ FLUS treatment groups.
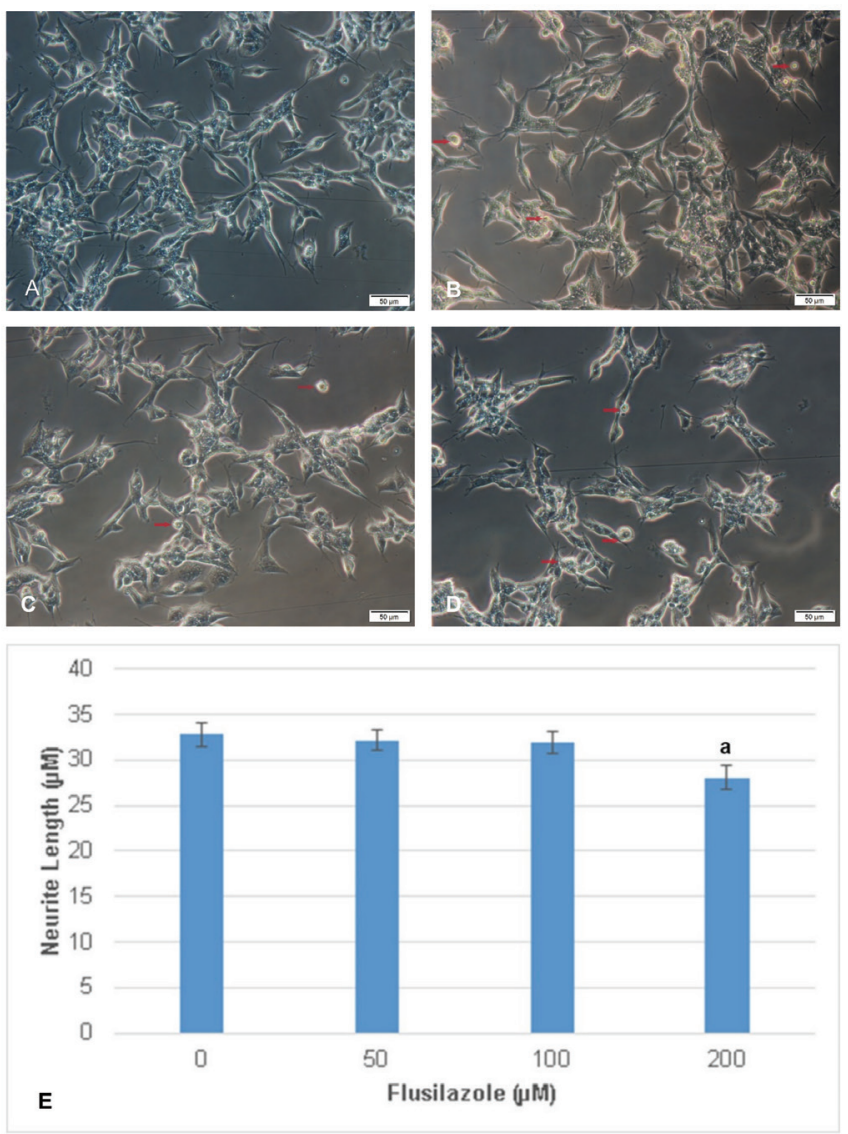

Figure 2. Morphological micrographs of differentiated SH-SY5Y cells in the FLUS treatment groups: A) Control group; B) 50- $\mu \mathrm{M}$ FLUS treatment group; C) $100-\mu \mathrm{M}$ FLUS treatment group; D) $200-\mu \mathrm{M}$ FLUS treatment group; $(\rightarrow)$ apoptotic cell

FLUS: Flusilazole

\section{DISCUSSION}

Triazole fungicides have been used globally in various areas including agriculture and medicine. However, excessive use of fungicides could leave harmful residues in the environment and cause risks in human health via consumption of contaminated food and water. ${ }^{17}$ For example, studies have shown that triazole

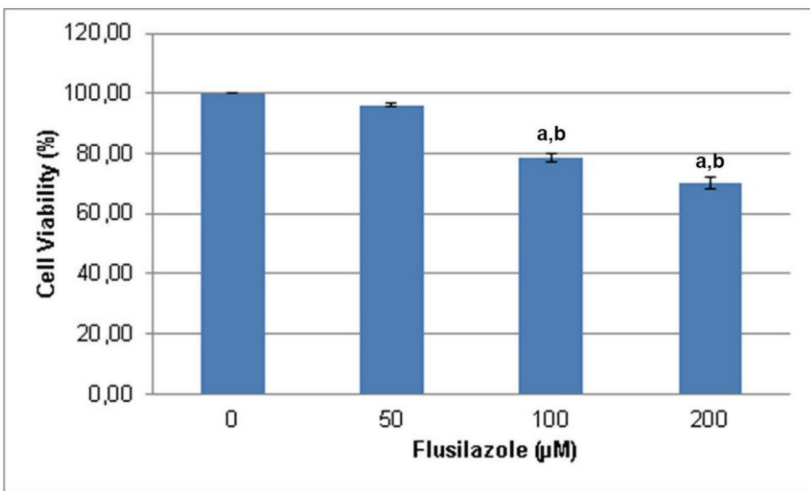

Figure 3. Crystal violet cell viability assay results (\%). aSignificantly

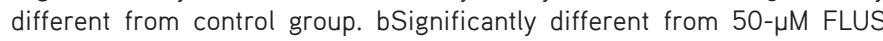
group

FLUS: Flusilazole

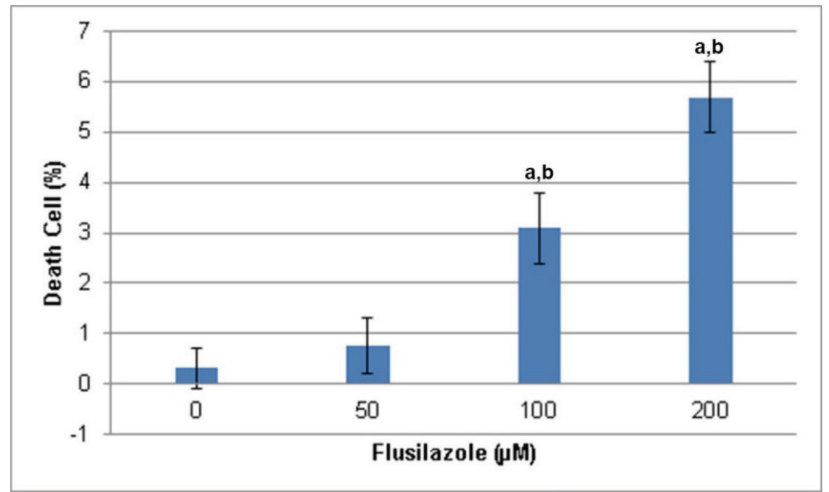

Figure 4. LDH leakage assay results, cell death (\%). aSignificantly different from control group. bSignificantly different from $50-\mu$ M FLUS group LDH: Lactate dehydrogenase, FLUS: Flusilazole

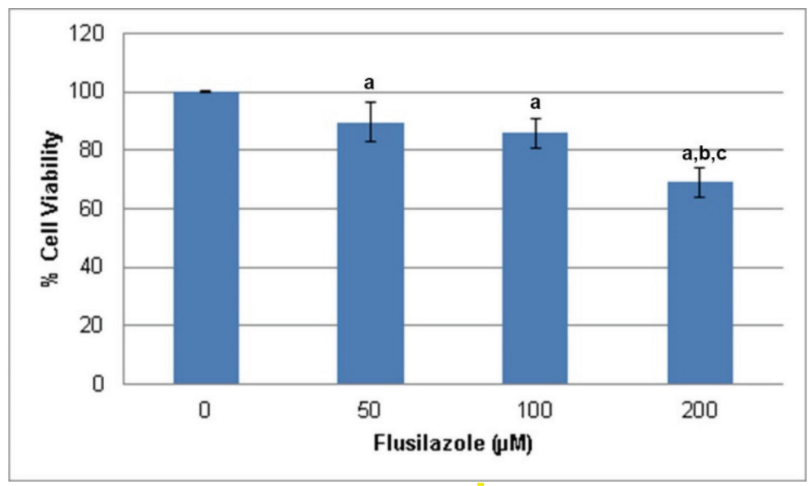

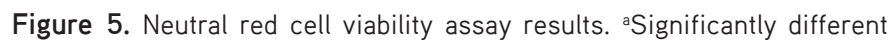

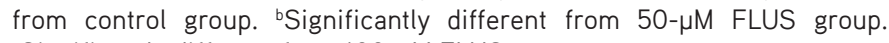
'Significantly different from 100- $\mu$ M FLUS group

FLUS: Flusilazole 
fungicides, which are used to inhibit fungal CYP51 and increase fungal cell wall permeability to kill fungi, ${ }^{6,7}$ cause harmful effects on the nervous system via neuropathological defects in the murine brain as well as neuropathological lesions in the peripheral nervous system. ${ }^{18}$ Other studies also reported several adverse effects of azole fungicides such as birth defects, craniofacial malformations, and inhibition of steroidogenesis in mammals. 5,19,20 Despite the wide range of risks in human health caused by triazole fungicides, studies about the effects of FLUS on human health are very limited. ${ }^{6,7}$ Because of the limited information on the effects of FLUS on differentiated neurons, this study aimed to elucidate the toxicity mechanism of FLUS on neurite outgrowth and to compare cytotoxicity tests using FLUS treatment.

In the field of neuroscience, in vitro models functionally resembling neurons are lacking, especially for neurodegenerative diseases including Alzheimer's disease. Although cell lines such as SH-SY5Y cells are often used, these cells lack mature neuronal functions and morphology, have ceased cell division, and express specific markers. ${ }^{21}$ However, SH-SY5Y cells could be differentiated into mature neuron, and differentiated neuron cells could serve as homogenous cell types, as demonstrated in previous studies where SH-SY5Y cells were differentiated into mature neuron-like cells by RA induction on a 7-day treatment in dark conditions, and differentiated cells morphologically changed as characterized by extensive neurites outgrowth. ${ }^{22,23}$ Hence, the present study aimed to investigate the cytotoxic mechanisms of FLUS on differentiated SH-SY5Y cells. The action mechanism of RA was characterized by the activation of transcription via binding to non-steroid nuclear hormone receptors. Additionally, RA was shown to induce the Wnt signaling pathway and play a role in the regulation of the neurotrophin receptor gene transcription. ${ }^{13}$ In this study, it was observed that morphologically differentiated SH-SY5Y cells had typical neurons with extensive neurites and pyramid-shaped cell bodies. On the other hand, undifferentiated cells tend to form clusters and had round-shaped cell bodies." According to these results, I can say that the morphological differentiation of $\mathrm{SH}-\mathrm{SY} 5 Y$ cells was successful.

In vitro cytotoxicity assays can be useful in determining toxicity levels in humans in toxicological studies. Cytotoxicity assays differ in the types of assays as well as results depending on the test principle. ${ }^{24}$ It is important to carry out multiple markers to exert reversible or irreversible effects of toxic substances. ${ }^{25}$ In this study, three cytotoxicity assays were performed based on different test principles for differentiated SH-SY5Y cells to evaluate the mechanism of toxicity. The crystal violet assay was selected to evaluate cell viability because of its reliable and quick method and because crystal violet specifically binds to DNA to reveal the cell viability. Neutral red uptake assay as performed to evaluate the percentage of cell viability in terms of lysosomal activity and the LDH leakage assay to evaluate necrotic cell death.

To evaluate the viability of differentiated SH-SY5Y cells, we performed crystal violet cell viability assay, which is a basic method for determining cell viability by staining with crystal violet dye that binds to DNA and proteins. This method depends on staining attached viable cells because dead cells lose their absorption and the amount of crystal violet dye is reduced. ${ }^{26}$ Results from this assay showed that FLUS treatment caused the decrease in differentiated SH-SY5Y cells in a dose-dependent manner. A previous study with 9.5-day-old rat embryos in vitro reported that triazole treatment altered hindbrain development and caused cranial nerve anomalies. The same study also found that FLUS and other triazole derivatives were teratogenic. ${ }^{20}$ The present study has shown that FLUS can induce cell death at higher concentrations, consistent with previous studies.

Results showed that the release of LDH, an intracellular enzyme found in the inner compartment of the cell, was significantly increased at higher concentrations in the FLUS treatment groups. Consequently, LDH leakage assay is described as a cytotoxicity marker that reveals cell membrane damage as irreversible cell death. ${ }^{27}$ As necrotic cells have permeable cell membrane, leakage of LDH into the culture media as a result of membrane damage is considered a hallmark of necrotic cell death. ${ }^{28}$ Hence, in the present study the LDH leakage assay was used to determine the necrotic cell death percentage. A previous study treated zebra fish liver cell line with triazole fungicides and evaluated the effects using LDH leakage assay. That study revealed remarkable increases in LDH leakage at higher concentrations of FLUS. ${ }^{29}$ Similarly, the results of the present study were consistent with the previously reported study as is another previous study that also used triazole fungicide to induce necrotic cell death in $L 929$ cells. ${ }^{30}$ The present study revealed that FLUS could adversely affect human neuronal cells as membrane damage occurred in differentiated SH-SY5Y cells after FLUS treatment, which eventually induced necrotic cell death.

The neutral red uptake assay was performed to determine cytotoxicity. The principle of this assay is based on the uptake of neutral red dye (a water-soluble dye) into the lysosomes, which processes energy required for cells. ${ }^{31}$ The neutral red uptake depends on $\mathrm{pH}$ gradients during the ATP production process. As the net charge of the dye is zero, neutral red dye could enter the cell. However, the interior of the lysosomes has a lower $\mathrm{pH}$ than the cytoplasm via proton gradient. Because of the $\mathrm{pH}$ gradient, the neutral red dye keeps the cytoplasm positively charged so that the dye could retain inside the lysosomes. Conversely, neutral red dye could not be retained in the lysosomes in case of cell death or $\mathrm{pH}$ gradient changes. Studies reported that this assay is highly sensitive to cell viability quantification. ${ }^{32}$ When plasma or lysosomal membranes are damaged by chemicals, the ability of the endocytosis, which requires energy for the process, to uptake the neutral red dye decreases. According to neutral red uptake assay results in this study, high concentrations of FLUS in SH-SY5Y cells adversely affected cell viability. These results indicate that FLUS may cause lysosomal damage especially at higher concentrations. All cytotoxicity test results demonstrated a downward trend in cell viability. Despite some variations, it seemed that the most 
sensitive test for FLUS in differentiated SH-SH5Y cells was the crystal violet assay.

Environmental neurotoxins including pesticides and fungicides have been reported to play a crucial role in the development of neurodegenerative disorders. ${ }^{33-35}$ In differentiated neurons, changes in morphology or neurite growth could be a sign of neurodegenerative diseases. To date, several cell lines including SH-SY5Y have been used to study the effects of chemicals on neurite growth ${ }^{36}$ Consequently, SH-SY5Y cells differentiated via RA induction could serve as a good in vitro model for revealing neurotoxicity mechanisms ${ }^{37}$ as differentiated SH-SY5Y cells were reported to have the longest neurite measurement after treatment with $10 \mu \mathrm{M}$ RA for 3 days. ${ }^{38}$ In the present study, differentiated SH-SY5Y cells had longer neurites than undifferentiated cells. Neurite growth induced by RA treatment were $>1.9$ fold compared with that in undifferentiated cells. Previous in vitro studies involving organophosphates reported a reduction in neurite outgrowth in N2a mouse neuroblastoma and C6 glioma cells, ${ }^{39}$ We observed that FLUS treatment caused the inhibition in neurite outgrowth of differentiated SH-SY5Y cells.

\section{CONCLUSION}

As mentioned earlier, FLUS is widely used as a fungicide in agriculture for preventing fungal diseases. However, intensive usage of these compounds has potential health risks for both humans and the environment. The present study has demonstrated that FLUS caused neurotoxicity at higher concentrations resulting in neuronal cell death and adversely affecting neurite growth in differentiated neurons, indicating that FLUS could cause neuronal degeneration in mammals. The results in this study may serve as preliminary data for further studies to elucidate the mechanism of action.

Conflict of interest: No conflict of interest was declared by the author. The author are solely responsible for the content and writing of this paper.

\section{REFERENCES}

1. Martin MT, Brennan RJ, Hu W, Ayanoglu E, Lau C, Ren H, Wood CR, Corton JC, Kavlock RJ, Dix DJ. Toxicogenomic study of triazole fungicides and perfluoroalkyl acids in rat livers predicts toxicity and categorizes chemicals based on mechanisms of toxicity. Toxicol Sci. 2007;97:595613.

2. de Jong $E$, Barenys $M$, Hermsen $S A B$, Verhoef $A$, Ossendorp $B C$, Bessems JGM, Piersma A. Comparison of the mouse embryonic stem cell test, the rat whole embryo culture and the zebrafish embryotoxicity test as alternative methods for developmental toxicity testing of six 1,2,4-triazoles. Toxicol Appl Pharmacol. 2011;253:103-111.

3. Farag AT, Ibrahim HH. Developmental toxic effects of antifungal flusilazole administered by gavage to mice. Birth Defects Res B Dev Reprod Toxicol. 2007;80:12-17.

4. Menegola E, Broccia ML, Di Renzo F, Giavini E. Antifungal triazoles induce malformations in vitro. Reprod Toxicol. 2001;15:421-427.
5. Zarn JA, Brüschweiler BJ, Schlatter JR. Azole fungicides affect mammalian steroidogenesis by inhibiting sterol 14 alpha-demethylase and aromatase. Environ Health Perspect. 2003;111:255-261.

6. Heusinkveld HJ, Molendijk J, van den Berg M, Westerink RH. Azole fungicides disturb intracellular $\mathrm{Ca} 2+$ in an additive manner in dopaminergic PC12 cells. Toxicol Sci. 2013;134:374-381.

7. Dimopoulou M, Verhoef A, van Ravenzwaay B, Rietjens IM, Piersma AH. Flusilazole induces spatio-temporal expression patterns of retinoic aciddifferentiation-and sterol biosynthesis-related genes in the rat Whole Embryo Culture. Reprod Toxicol. 2016;64:77-85.

8. Mineshima H, Fukuta T, Kato E, Uchida K, Aoki T, Matsuno Y, Mori C. Malformation spectrum induced by ketoconazole after single administration to pregnant rats during the critical period - comparison with vitamin A-induced malformation spectrum. J Appl Toxicol. 2012;32:98-107.

9. Food and Agriculture Organization of the United Nations, World Health Organization, FAO Panel of Experts on Pesticide Residues in Food and the Environment \& WHO Core Assessment Group on Pesticide Residues. (2009). Pesticide residues in food: 2007, Toxicological Evaluations Last Accessed Date: 02.01.2021. Available from: https:// apps.who.int/iris/handle/10665/44064

10. Krishna A, Biryukov M, Trefois C, Antony PM, Hussong R, Lin J, Heinäniemi M, Glusman G, Köglsberger S, Boyd O. Systems genomics evaluation of the SH-SY5Y neuroblastoma cell line as a model for Parkinson's disease. BMC Genomics. 2014;15:1154.

11. Kovalevich J, Langford D. Considerations for the use of SH-SY5Y neuroblastoma cells in neurobiology. Neuronal cell culture. London: Springer; 2013:9-21.

12. Janesick A, Wu SC, Blumberg B. Retinoic acid signaling and neuronal differentiation. Cell Mol Life Sci. 2015;72:1559-1576.

13. Xie HR, Hu LS, Li GY. SH-SY5Y human neuroblastoma cell line: in vitro cell model of dopaminergic neurons in Parkinson's disease. Chin Med J. 2010;123:1086-1092.

14. Akinrinde $\mathrm{A}$, Koekemoer $\mathrm{T}$, Van De Venter M, Bradley G. In vitro investigation of potential anti-diabetic activity of the corm extract of Hypoxis argentea Harv. Ex Baker. Acta Pharm. 2018;68:389-407.

15. Pemberton K, Mersman B, Xu F. Using ImageJ to assess neurite outgrowth in mammalian cell cultures: research data quantification exercises in undergraduate neuroscience lab. J Undergrad Neurosci Educ. 2018;16:A186.

16. Schneider CA, Rasband WS, Eliceiri KW. NIH Image to ImageJ: 25 years of image analysis. Nat Methods 2012;9:671-675.

17. Faro LRF. Neurotoxic effects of triazole fungicides on nigrostriatal dopaminergic neurotransmission. Fungicide. 2010:405-420.

18. EPA. Reregistration eligibility decision for triadimefon and tolerance reassessment for triadimenol. 2006. Available from. https://archive.epa. gov/pesticides/reregistration/web/pdf/triadimefon_red.pdf

19. Crofton K. A structure-activity relationship for the neurotoxicity of triazole fungicides. Toxicol Lett. 1996;84:155-159.

20. Menegola E, Broccia ML, Di Renzo F, Massa V, Giavini E. Study on the common teratogenic pathway elicited by the fungicides triazolederivatives. Toxicol In Vitro. 2005;19:737-748.

21. Agholme L, Lindström T, Kågedal K, Marcusson J, Hallbeck M. An in vitro model for neuroscience: differentiation of SH-SY5Y cells into cells with 
morphological and biochemical characteristics of mature neurons. J Alzheimers Dis. 2010;20:1069-1082.

22. Cheung YT, Lau WK, Yu MS, Lai CS, Yeung SC, So KF, Chang RC. Effects of all-trans-retinoic acid on human SH-SY5Y neuroblastoma as in vitro model in neurotoxicity research. Neurotoxicology. 2009;30:127-135.

23. Sarkanen JR, Nykky J, Siikanen J, Selinummi J, Ylikomi T, Jalonen TO. Cholesterol supports the retinoic acid-induced synaptic vesicle formation in differentiating human SH-SY5Y neuroblastoma cells. J Neurochem. 2007;102:1941-1952.

24. Weyermann J, Lochmann D, Zimmer A. A practical note on the use of cytotoxicity assays. Int J Pharm. 2005;288:369-376.

25. Rausch O. High content cellular screening. Curr Opin Chem Biol. 2006;10:316-320.

26. Feoktistova M, Geserick P, Leverkus M. Crystal violet assay for determining viability of cultured cells. Cold Spring Harbor Protocols. 2016;2016:pdb. prot087379.

27. Fotakis G, Timbrell JA. In vitro cytotoxicity assays: comparison of LDH, neutral red, MTT and protein assay in hepatoma cell lines following exposure to cadmium chloride. Toxicol Lett. 2006;160:171-177.

28. Chan FK, Moriwaki K, De Rosa MJ. Detection of necrosis by release of lactate dehydrogenase activity. Methods Mol Biol. 2013;979:65-70.

29. Bopp SK, Lettieri T. Comparison of four different colorimetric and fluorometric cytotoxicity assays in a zebrafish liver cell line. BMC Pharmacol. 2008;8:8.

30. Süloğlu AK, Karacaoğlu E, Koçkaya EA, Selmanoğlu G, Loğoglu E. Cytotoxic effects of a novel thialo benzene derivative 2, 4-dithiophenoxy1-iodo-4-bromobenzene $\left(\mathrm{C}_{18} \mathrm{H}_{12} \mathrm{~S}_{2} \mathrm{IBr}\right)$ in $\mathrm{L929}$ cells. Int J Toxicol. 2014;33:319-324

31. Putnam K, Bombick D, Doolittle D. Evaluation of eight in vitro assays for assessing the cytotoxicity of cigarette smoke condensate. Toxicol In Vitro. 2002;16:599-607.
32. Repetto G, del Peso A, Zurita JL. Neutral red uptake assay for the estimation of cell viability/cytotoxicity. Nat Protoc. 2008;3:1125-1131.

33. Sanchez M, Gastaldi L, Remedi M, Cáceres A, Landa C. Rotenone-induced toxicity is mediated by Rho-GTPases in hippocampal neurons. Toxicol Sci. 2008;104:352-361.

34. Kara M, Oztas E, Ramazanoğulları R, Kouretas D, Nepka C, Tsatsakis AM, Veskoukis AS. Benomyl, a benzimidazole fungicide, induces oxidative stress and apoptosis in neural cells. Toxicol Rep. 2020;7:501-509.

35. Kanat ÖN, Selmanoğlu G. Neurotoxic effect of fipronil in neuroblastoma SH-SY5Y cell line. Neurotox Res. 2020;37:30-40.

36. Itano Y, Nomura Y. 1-Methyl-4-phenyl-pyridinium ion (MPP+) causes DNA fragmentation and increases the $\mathrm{Bcl}-2$ expression in human neuroblastoma, SH-SY5Y cells, through different mechanisms. Brain Res. 1995;704:240-245.

37. Pak EJ, Son GD, Yoo BS. Cadmium inhibits neurite outgrowth in differentiating human SH-SY5Y neuroblastoma cells. Int J Toxicol. 2014;33:412-418.

38. Dwane S, Durack E, Kiely PA. Optimising parameters for the differentiation of SH-SY5Y cells to study cell adhesion and cell migration. BMC Res Notes. 2013;6:1-11.

39. Almami IS, Aldubayan MA, Felemban SG, Alyamani N, Howden R, Robinson AJ, Pearson TDZ, Boocock D, Algarni AS, Garner AC, Griffin M, Bonner PLR, Hargreaves AJ. Neurite outgrowth inhibitory levels of organophosphates induce tissue transglutaminase activity in differentiating N2a cells: evidence for covalent adduct formation. Arch Toxicol. 2020;94:3861-3875. 